\title{
WOMEN'S PLACE OF SPEECH IN THE LITERATURE OF SURINAME: CHALLENGING GENDER AND RACE PARADIGMS
}

\author{
O LUGAR DE FALA DAS MULHERES NA LITERATURA DO SURINAME: \\ DESAFIANDO OS PARADIGMAS DE GÊNERO E RAÇA
}

Natali Fabiana da Costa e Silva ${ }^{1}$

\begin{abstract}
Suriname is located in the extreme north of South America in a region called Guyana Shield, that includes French Guiana, Republic of Guyana, Suriname and part of Venezuela and northern Brazil. It's literature is marked by cultural and linguistic ethnic plurality and the thematization of social contradictions. In the case of the literature of Suriname, the narratives that compose this space inscribed in the heterogeneity are populated by characters historically silenced, as enslaved women, workers of the plantations, "bushnengués", among others, but who speak, despite being intermediated by a writer, as representatives of cultures not valued and/or little known. In this sense, this article will discuss two Surinamese historical novels written by Cynthia McLeod,The free negress Elisabeth: prisoner of color (2004) and Tutuba: the girl from the slave-shipLeudsen(2013), addressing, more specifically, how her literature questions the current literary paradigms and discusses the problematic of women's voices, whose legitimacy is continually put in question.

Key-words: gender and race; place of speech; subalternity; literature of Suriname; historical novel.
\end{abstract}

Resumo: O Suriname está localizado no extremo norte da América do Sul em uma região denominada Platô das Guianas, que compreende a Guiana Francesa, a República da Guiana, o Suriname e parte da Venezuela e do norte do Brasil. Sua literatura é marcada pela pluralidade étnico cultural e linguística e pela tematização de contradições sociais. No caso da literatura do Suriname, as narrativas que compõem esse espaço inscrito na heterogeneidade estão povoadas de personagens silenciadas historicamente, como mulheres escravizadas, trabalhadores das lavouras, quilombolas, entre outras, mas que falam, apesar de intermediados por um escritor ou uma escritora, enquanto representantes de culturas não valorizadas e/ou pouco conhecidas. Nesse sentido, este artigo discutirá dois romances históricos da autoria de Cynthia McLeod, The free negress Elisabeth: prisoner of color (2004) eTutuba: the girl from the slave-ship Leudsen (2013), abordando, mais especificamente, o modo como sua literatura questiona os paradigmas literários vigentes e discute a problemática davoz feminina, cuja legitimidade é continuamente posta em questão.

Palavras-chave: gênero e raça; lugar de fala; subalternidade; literatura do Suriname; romance histórico.

\section{Introduction}

This article intends to discuss the literary production by the Surinamese writer Cynthia McLeod aiming toexamine the way her literature questions current literary paradigmsand discusses the problematic of voices whose legitimacy is continually questioned, that is, the female voices.In order to understand McLeod's characters place of speech and the context of her writing, it will be rather necessary to understand about the region where this literature is inserted, such as its

\footnotetext{
${ }^{1}$ Doutora em Estudos Literários pela Universidade Estadual Paulista. Professora de Teoria Literária na Universidade Federal do Amapá. Líder do Núcleo de Pesquisas em Estudos Literários (NUPEL). E-mail: natali costa@hotma il.com; http://lattes.cnpq.br/4523010397725244
}

https://periodicos.unifap.br/index.php/letras

Macapá, v. 9, n. 2, $2^{\circ}$ sem., 2019 
geography, social, cultural and linguistic characteristics, as well as the perception that people from this region have about themselves.

The Guyana region is located in the extreme north of South America.It comprehends French Guiana, Suriname, the Republic of Guyana (formerly English Guiana), Amapá as well as part of Venezuela and Roraima². Although located in South America, it has little interconnectivity with the region,both politically and structurally,featuring few highways and a limited number of flights connecting the territory. On the other hand, it is a place of great relations with the Caribbean and, therefore the region is also known as the "Caribbean Amazon"and houses the Caribbean Communityheadquarters (CARICOM) in Georgetown, in the Republic of Guyana.In this space, the river, a fundamental and structuring element for the population, represents life, exit to other spaces and the source of the riverside community livelihood. Placed in the heart of the Amazon rainforest, it is influenced by nature, since river transport, which is very common in the region,or an outdoor event,just to cite a few examples, occur depending on the rainfall calendar or the tide table.

The plurality of Guyana lies in the diversity of peoples who live there or in the migratory process that characterizes this territory andcomposes the sociocultural and linguistic mosaic.Although it houses, from the economic point of view, an ultra-peripheral condition(CORREA, 2014) with lack of sanitation and alarming educational indices, for example,the region has the presence of the European Union through French Guiana,which is a French overseas territory. This means that alongside poor countries like Suriname and the Republic of Guyana, and also one of the most needy Brazilianstates, such as Amapá, there is a place with European education, medicine and structure.Despite this superior condition in relation to its geographical surroundings, even French Guyana has low rates of economic and social development. Correa states:

Generally [French Guyana] has lower development rates than its metropolis and it is a low density territory like Azores and Madeira, belonging to Portugal, and Canary Islands in relation to Spain. [...] The peripheral condition from French Guiana and its distance from the political decision center does not mean a lower state presence. On the contrary, there is a strong influence of metropolitan France in the Department, stimulating economic and political dependence on the central power and the European Union, which means the presence of an external power within the transnational Amazon. (CORREA, 2014, p.98) ${ }^{3}$

Alongside French Guiana, the Republic of Guyana and Suriname are the youngest countries in South America,with independence in 1960 and 1975, respectively.In the case of Suriname, poverty and inequality levels are high,but gold mining and related services such as food, transportation, commerce and prostitution are strong attractions for the flow of migration. Besides Brazilians, immigrations established Javanese, Haitian, Chinese, and Indian communities, and this diversity of peoples also brings a diversity of languages and cultural and religious influences. Thus, in Suriname, you can find the Dutch, French, Portuguese, English, Javanese, Chinese, Creole and indigenous languages, as well as various artistic expressions. The literature produced there is marked by this cultural and linguistic ethnic plurality, by the thematization of social contradictions and by the discourse on the marginalization of a region that became known as "Green Hell".

With little reverberation in South America and almost no prestige outside the Guyana ter-

\footnotetext{
2 Amapá and Roraima are Brazilian states located in the Amazon region.

3 Translation of the original text in Portuguese: "De forma geral, [a Guiana Francessa] apresenta índices de desenvolvimento menores que sua metrópole e é território de baixa densidade como Açores e Madeira, pertencentes a Portugal, e Ilhas Canárias em relação à Espanha. [...] A condição ultraperiférica da GF [Guiana Francesa] e sua distância do centro de decisão política não significa uma menor presença do Estado. Ao contrário, existe uma forte influência da França metropolitana no Departamento, estimulando uma dependência econômica e política do poder central e da União Europeia, o que significa a presença de uma potência externa dentro da Amazônia transnacional".
} 
ritory, the narratives written in this heterogeneousspace are populated by historically silenced characters, as enslaved women, crop workers, "bushnengués", among others. They speak, although brokered by a writer, as representatives of undervalued cultures. Embracing Suriname's geographical isolation from the so-called major knowledge-producing centers, we see a literature that claims to be in the margins and seeks to speak from there.The diversity of perceptions of the world through marginalized voices, or ex-centric voices, seeks the recognition of plurality and difference and thereforeit can also be interpreted as a sign of resistance, bringing up the problematic of the legitimacy of discourse. According to Dalcastagnè,

The discourse control [...] is the denial of the right to speak to those who do not fulfill certain social requirements: a veiled social censorship that silences the dominated groups. [...] It's fundamental to realize that this is not just about being able to speak [...],but the possibility of "speaking with authority", that is, the social recognition that a speech has a value and therefore it deserves to be heard. (DALCASTAGNÈ, 2012, p.19) ${ }^{4}$

When writers in a region considered by major centers to be "peripheral" give voice tothe voiceless, that is, to a fictional character that have never had voice in novels, they not only challenge hegemonic discourses, but, "also our own beliefs as readers and producers of knowledge and wisdom" (SPIVAK, 2010, p.09) ${ }^{5}$.The desire to reconstruct the historical past and to give voice to the silenced individuals (or, in Spivak's words, subalterns ${ }^{6}$ ) is the base of the Surinamese literature. Past events can be altered, history can be rewritten, for "both fiction and history are cultural systems of signs, ideological constructs whose ideology includes their appearance as autonomous and self-sufficient" (HUTCHEON, 1991, p. 149)7

The writing of history, as Hutcheon points out, contrasts with the Aristotelian notion (1982) that the historian could speak only of what happened, while the poet would speak of what might happen. For the researcher, it is necessary to confront the paradoxes of fictitious/historical representation, since both are historically determined and limited discursive constructions that, therefore, vary over time.The "desire to rewrite the past within a new context" (HUTCHEON, p.157) ${ }^{8}$ occurs primarily by the recognition that this subaltern/marginalized individual is not a monolithic and undifferentiated category, but rather an irreducibly heterogeneous being. Hence, character types have almost no place in the novels of Suriname, because one of the fundamental points of this literature is not to fall into exoticism or into picturesque descriptions of an Amazon whose natural mysteries conquered the reader more than the uniqueness of its inhabitants.

It is necessary to take into consideration the prevalence of memory as social and identity representation. According to Gagnebin (2005) one cannot subtract individual memory out of a collective memory because memory is impregnated, embedded, crossed by the social environment of which the individual is part. The identity construction implies the narration of oneself, built from the many histories of the individual and his participation in a wider life. Bosi (1979)agrees with this idea. For her, the identity construction is linked to narration and in this sense, a narrative is built through collective stories. These collective stories gradually create a story of the individual. In other words, when we remember certain events, much of our memory is linked to the experiences of other witnesses who also experienced the same event as family, fri-

\footnotetext{
${ }^{4}$ Translation of the text in Portuguese: $\mathrm{O}$ controle do discurso [...] é a negação do direito de fala àqueles que não preenchem determinados requisitos sociais: uma censura social velada, que silencia os grupos dominados. [...] $\mathrm{O}$ fundamental é perceber que não se trata apenas da possibilidade de falar [...], mas da possibilidade de "falar com autoridade", isto é, o reconhecimento social de que o discurso tem valor e, portanto, merece ser ouvido.

5 Translation from the Brazilian edition.

${ }^{6}$ According to Spivak, the subaltern individual is the one excluded from the market, from political and legal representation, and unable to fully participate in the dominant social extract.

7 Translation from the Brazilian edition.

${ }^{8}$ Translation from the Brazilian edition.
} 
ends, neighbors, community colleagues. Therefore, collective memory is not a pure evocation of the past, but a "refaction" of it, since, in Bosi's words, "remembering is often not relive, but remake, reconstruct, rethink, with images and ideas of today, the experiences of the past"'(1979, p.17) .

In order to illustrate these reflections, we are interested in highlighting Cynthia McLeod's novels, The Free Negress Elisabeth: Prisoner of Color (2004) and Tutuba: The Girl from the Slaveship Leusden (2013). These are historical novels that value the feminine perspective in the colonial period in order to deconstruct the view in which women of this period was submissive.

The free negress Elisabeth: prisoner of colomarrates the life of Elisabeth Samson (1715-1771), a free-born black woman who lived in Suriname in one of the most cruel periods of slavery.Despite poignant racism, Samson managed to be the richest woman in the entire territory, as she owned numerous coffee and sugarcane farms, a concession for timber extraction and trade, and lent money to farmers - white farmers, it is important to point out - at interest. She alsodominated the real estate market, as well as the business of fabrics, hats, wigs, among others.

Everyone recognized her as one of the most successful person in the colony, however notwithstanding her financial success, racism prevented her from being part of the social wheels, and of course she was treated with scorn and often harshness by the local high society. The hatch attitude of the colonial elite towards her reveals the protagonist paradoxical condition already announced in the title and subtitle of the novel, since although free, Elisabeth feels she is a prisoner of her own color.

Before McLeod's novel, Elisabeth Samson's story wasalready very famous in Suriname, but the source of her financial enrichment is commonly attributed to an inheritance of uncertain origin, rather than to Elisabeth's personal efforts.After thorough research in the Hague City National Archives, the Amsterdam and Rotterdam District Archives, and finally the Keulen and Emmerich Archives in Germany ${ }^{10}$, McLeod concluded that the version that creditsSamson's enrichment by inheritance is, to say the least, reproductive of the prospect of white and macho supremacy.The long citation of the novel preface is justified because it highlights the author's indignation regarding this fact, as can be observed:

The Free Negress Elisabeth, who in the last years of her life took the name Samson, ensured herself a permanent and unrivalled place in the annals of colonial history - particularly Dutch - on 2 counts: First, her request in 1764 to marry a white man; and second, on account of her extreme wealth - she was a self-made black business magnate in the 18th century at the height of slavery. Many historians wrote about this fact: J.J. Hartsinck, J. G. Stedman, J. Wolbers. R.A.J. Van Lier, Lichtveld em Voorhoeve. Althou they did not write in the same words, they all assumed that Elisabeth Samson was a slave woman who had cohabited with a white or Jewish man, who set her free and made her his heir. [...] I searched in the National Archives in The Hague, in the district archives of Amsterdan and Rotterdam, in the archives of Keulen and Emmerich in Germany. After a while I had collected so many documents, that I could prove that the historians were absolutely WRONG, and the statements that she surely must have inherited her wealth from a slave master who set her free, told us something about the historians, but not about Elisabeth. It was excellent proof of machismo and white supremacist thinking: "When a black woman is rich, she can only have gained her wealth thanks to a White Man, who made her rich!” In Elisabeth's case it was the contrary!!! (McLEOD, 2004, p.06).

McLeod calls into question the phallocentric view through a novel that seeks to deconstruct prejudice against black women, who suffer doubleand most cruel discrimination: gender and race.Samson's qualities as an educated woman, diligent in conducting business and, above all, aware of her different status from the other black people of the time are crucial in the construc-

\footnotetext{
9 Translation from the Brazilian edition.

10 The documents accessed by the author are informed in the novel The free negress Elisabeth: prisoner of color in endnote.
} 
tion of the plot.In the introduction to the novel, the author tries to explain the idiosyncrasies of the Surinamese colonial society in order to situate the reader in relation to the difficulties faced by black people who, besides suffering severe punishments, were prohibited from marrying white people, even after being freed from slaveship, under penalty of capital crime ${ }^{11}$.

In this respect, Elisabeth was revolutionary because she fought for interracial marriage to be sanctioned. She thus used the legitimacy that money can gain for a noble cause: the transformation of a society. Samson understood that social change would only happen when introduced in the rule of law and for this, she made no effort to succeed.

In Tutuba: The Girl from the Slave Ship Leusden(2013), McLeod narrates the life of Tutuba, a young inhabitant of Elmina in Ghana, who is kidnapped on the eve of her wedding to be brought to Suriname to work as a slave.The sinking of the ship Leusden, which carried Tutuba along with 664 other prisoners, is considered to be the biggest accident involving such a vessel, however, the fact remained forgotten and/or ignored until the author rescues the event and gives voice to those who had never been remembered by the history before, as she pointed out in the preface:

The sinking of the slave ship Leusden, in which six hundred and sixty-four prisoners and abducted Africans lost their lives, attracted hardly any attention at the time. In the ensuing years, too, no mention has ever been made of it. In fact it was the greatest disaster involving a slave ship in the whole three-hundred-year history of the transatlantic slave trade, and involved the greatest loss of life. Dr. Leo Balai 'discovered' this disaster by chance. Thanks to this research, spanning several years, the Leusden has been 'salvaged' after almost three hundred years [...]. (McLEOD, 2014, p.05)

The internal focalization in the protagonist, who names McLeod's novel, shows how the process of enslavement empties the individual from his culture and dignity.On the way from Ghana to Suriname, facing psychological and physical torture, rapes, violence and, finally, enduring the manifest reality that they would never return to their homeland, the enslaved people who survived the sinking of Leusden slowly learned about the new territory they were heading to, like its language (the sranantongo) and the habits of a place that was organized, on the one hand, by the concentration of slave labor, but on the other hand, revealed the plurality of cultures that would constitute postcolonial Suriname with the arrival of people from many regions.

In both Tububa: The Girl from the Slave Ship Leusden and The Free Negress Elisabeth: Prisoner of Color, McLeod pushes the boundaries of fiction with the aim of rewriting historical discourse.In each preface or presentation, she is nonetheless in favor of revising the ethnocentric perspective that guides historical and literary texts. Another point that deserves attention in McLeod's novels is the language used as an instance of valuing cultural elements.In Tutuba, for example, the author chooses to present in sranantongo (in footnote) the dialogues that in the body of the text are written in English: "sigh, my child, sigh. If we couldn't sigh and moan, our hearts would break. "(McLEOD, 2013, p.99) has its correspondence in sranan: "geme mi pikin! Ay, geme nomo nomo. Efu geme no bem de, un hati bem sa priti" (p.100).In The Free Negress Elisabeth, the standard English variant is presented through the speech of the enslaved characters, highlighted by quotation marks as we see below:

\footnotetext{
"Dey gon either pierce her tongue with awls or she go'n get a hundred lashes."

"I think dey gon cut off her tongue and d'en her ears."

"Oh, she going to be sentenced to death before dey torture and burn her alive."

$[\ldots]$

"No, no! Yuh all talking stupid. What you're talking are punishments for slaves. Misi Elisabeth is no slave. Dey can't do this to her."
}

\footnotetext{
${ }^{11}$ In colonial Suriname, any black man who had a physical relationship with a white woman was punished with death. However, this law did not apply to black women, who could establish a concubinage relationship with white men.
} 
"Yu hush with yu talk about slave or no slave. She's black. She's a Negro, like yu and me; and she'll find out soon." (McLEOD, 2003. p.97-98).

In the dialogue between the two enslaved, the marks of orality draw attention to social and racial disparity. The quotes placed by the writer reinforce this disparity while mark the place of speech of the excluded.Black identity is seen in the language and it is through it that McLeod imprintsher struggle, for as a woman, as a black woman, as a writer from a peripheral region she carries out the famous adage "The pen is mightier than the sword".

\section{Final considerations}

McLeod's writing as a political act largely combines awareness of gender and race difference with the need of thinking about one's identity. Thus, the writer's quest is to revive through her historical novels the memory of a people, their origins and struggles but froma brand new angle of history: from the oppressed point of view. Not rarely in her narratives thelanguage deconstructs socially widespread patterns. This posture engenders the creation of spaces of resistance and representation. Her novels tension the boundaries of fiction once in the prefaces or presentations McLeod admits she is in favor of revising the ethnocentric perspective that guides the historical and literary texts. In addition to criticizing the established colonization model, for McLeod the historical rescue of the slavery period reveals, even indirectly, the cultural mosaic that underlies Surinamese society and the appreciation of language as an identity element.

It is necessary to understand that literature, as a form of representation, conveys interests, values, perspectives. It is up to us, researchers in the field, a greater awareness of the important role we play in the legitimation of these literatures that challenge the current paradigm. This is not to say that as a researcher in the field of literature one must speak for minorities, but one must question the very place from which one theorizes. Remember that, according to Spivak (2010) the term "representation" in German has two meanings: "vertretung", which refers to the act of taking the place of the other (and in this process the word has a political meaning), and "darstellung", linked to an aesthetic view. This means, in Dalcastagnè's words (2012, p. 17), that "what arises is no longer simply the fact that the literature provides certain representations of reality, but rather that these representations are not representative of the whole of social perspectives" ${ }^{\prime 2}$. Finally, regarding McLeod's literature, it is possible to say that the common element of her novels is the creation of "true 'universes of speech' (BOSI, 1979, p.27) ${ }^{13}$ in which the past, when re-signified in the light of the present, when pronounced by voices once silenced, illuminates hidden aspects in a story that used to select only certain points of view and promoted a consecrated version of events. In McLeod, memory, race and gender emerge as identity trait, highlighting the appreciation of another story and other voices.

\section{References}

BOSI, Ecléa. Memória e sociedade: lembrança de velhos. São Paulo: T. A. Queiróz, 1979. CORREA, Paulo Gustavo Pellegrino. Integração e segurança na Amarônia transnacional. 2014. 185 f. Tese (Doutorado) - Curso de Doutorado em Ciências Humanas, Universidade Federal de São Carlos, São Carlos, 2014.

DALCASTAGNÈ, Regina. Literatura brasileira contemporânea: um território contestado. Rio de Janeiro: EdUERJ, 2012.

GAGNEBIN, Jeanne-Marie. Sete aulas sobre linguagem, memória e história. Rio de Janeiro: Imago, 2005.

\footnotetext{
${ }^{12}$ Translation from the Brazilian edition.

13 Translation from the Brazilian edition.
} 
HALBWACHS, Maurice. A memória coletiva. Tradução de Beatriz Sidou. São Paulo: Centauro, 2003.

HUTCHEON, Linda. Poética do pós-modernismo: história, teoria, ficção. Rio de Janeiro: Imago Ed., 1991.

McLEOD, Cynthia. Tutuba: the girl from the slave-ship Leudsen. Paramaribo, Suriname: The Waterfront Press, 2013.

. The free negress Elisabeth: prisoner of color. Suriname: The Waterfront Press, 2004.

SPIVAK, Gayatri Chakravorty. Pode o subalterno falar? Belo Horizonte: Editora da UFMG, 2010.

Envio: 30/10/2019

Aceite: 08/11/2019 